JESTT Vol. 1 No. 2 Februari 2014

\title{
PENGARUH PENGETAHUAN PRODUK TERHADAP KEPUTUSAN MENJADI DONATUR BAITUL MAAL HIDAYATULLAH CABANG KEDIRI
}

\author{
Dita Permata Syafitri \\ Mahasiswa Program Studi S-1 Ekonomi Islam - Fakultas Ekonomi dan Bisnis - Universitas \\ Airlangga

\begin{abstract}
Atina Shofawati
Departemen Ekonomi Syariah - Fakultas Ekonomi dan Bisnis - Universitas Airlangga Email: atinashofawati@yahoo.com
\end{abstract}

\begin{abstract}
This research aims to discover the influences of product knowledge including product knowledge product knowledge as bundle of attributes, product knowledge as bundle of benefits, and product knowledge as value satisfiers towards the decision of being donors in Baitul Mall Hidayatullah Branch Kediri, especially in the middle of development of Intitution of Alms Amil (Amil Zakat) in Indonesia.

This research uses quantitave descriptive approach. The sampling technique used in this research is probability sampling, i.e. a sampling technique which provides equal opportunity to each member of the population to be selected as sample members. The sampling is conducted by using simple random sampling. The number of samples in this research is 75 people. The technique analysis which is used is analysis of multiple linear regressions.

The results of the research show that there is similarity of regression $Y=0,409+0,473 X_{1}+$ $0,194 X_{2}+0,214 X_{3}$. Product knowledge has simultaneously influenced the decision of being donors in Baitul Mall Hidayatullah Branch Kediri with $R$ Square 0, 594. Product knowledge including product knowledge as bundle of attributes, product knowledge as bundle of benefits, and product knowledge as value satisfiers has partially influenced the decision of being donors. The variable of product knowledge as bundle of attributes appears to be dominant in influencing the decision of being donors.

Baitul Mall Hidayatullah Branch Kediri is suggested to improve the content of its bulletin. The bulletin distributed to prospective donors or donors should contain more complete, informative, and educative information since it plays quite important roles. The government is also expected to support the program of alms (zakat) centralization to be used as social importance and to reduce the poverty in Indonesia, instead of being in debt.

Key words: product knowledge, purcashing decisions of donors, product knowledge as bundle of attributes, product knowledge as bundle of benefits, product knowledge as value satisfiers.

\section{PENDAHULUAN}

\section{A. Latar Belakang}

Islam mewajibkan bagi seorang muslim yang mampu untuk mengeluarkan hartanya dalam bentuk zakat, infaq dan shadaqah. Zakat inilah yang diharapkan mampu meminimalisir kesenjangan antara yang kaya dan yang miskin, sebagai sikap dari saling membantu dan solidaritas dalam Islam yang pada akhirnya mampu

pula memberantas kemiskinan dalam masyarakat. Qardhawi (Nuruddin, 2006:152) mengemukakan bahwa zakat adalah sistem sosial karena zakat berfungsi menyelamatkan masyarakat dari kelemahan, baik karena bawaan ataupun karena keadaan. Zakat dapat menanggulangi berbagai bencana dan kecelakaan, memberikan santunan kemanusiaan, orang yang berada menolong yang tidak punya, yang kuat
\end{abstract}


membantu yang lemah, orang miskin dan orang yang dalam perjalanan kehabisan bekal dan memperkecil perbedaan antara si kaya dan si miskin.

Hafidhuddin, dalam acara workshop internasional zakat, infaq dan perkonomian Islam di Bogor (2013), menyatakan dari data riset Badan Amil Zakat Nasional (BAZNAS) dan Fakultas Ekonomi dan Manajemen Institut Pertanian (IPB) Bogor pada tahun 2011 mencatat bahwa potensi zakat di Indonesia mencapai Rp 217 triliun atau setara dengan 3,4 persen Produk Domestik Bruto (PDB) Republik Indonesia yang terdiri dari zakat perorangan, zakat industri kecil dan menengah serta zakat dari Badan Usaha Milik Negara (BUMN), namun baru terserap dan terkelola $\mathrm{Rp} 2,73$ triliun atau hanya satu persennya saja.

Besarnya jumlah muzakki dan potensi tersebut tidak diimbangi dengan kesadaran mereka yang lebih senang menyalurkan zakatnya melalui masjid sekitar lingkungan rumah ataupun secara langsung kepada mustahiq. Padahal pengelolaan zakat lewat masjid umumnya tidak seoptimal dan profesional seperti lewat Lembaga Amil Zakat. Pola pengelolaan zakatnya biasanya bersifat pasif, tentatif atau tidak rutin, booming pada saat Ramadhan, dikelola oleh panitia sementara, dan pendayagunaannya hanya pada pemenuhan kebutuhan pokok masyarakat, pendistribusian dan penyaluran pun tidak tersebar merata atau hanya terbatas pada mustahia di lingkungan sekitar.

Masih rendahnya pemahaman masyarakat akan pemahaman Islam apalagi masalah kesadaran untuk menyalurkan zakat secara kolektif melalui lembaga zakat maka lembaga amil zakat harus terus berkembang dan memperbaiki kinerjanya. Seperti yang dirilis http://nusaonline.com pada tanggal 16 Agustus 2013, fenomena yang terjadi sekarang ini adalah berkembang pesatnya dan bermunculan lembaga amil zakat yang mengelola dana zakat, infaq, shodaqoh dan wakaf. Lembaga amil zakat akan semakin tinggi lagi pertumbuhannya apabila masyarakat mempunyai permintaan dan antusiasme yang tinggi dikarenakan faktor peningkatan pemahaman dan pengetahuan tentang lembaga amil zakat, disamping faktor penyebab lainnya.

Pemahaman yang rendah terhadap lembaga zakat salah satunya diakibatkan kurang dan masih bersifat parsialnya sosialisasi yang dilakukan terhadap prinsip dan sistem. Dengan demikian hal tersebut mempengaruhi persepsi dan dan sikap masyarakat terhadap lembaga zakat. Maka tugas penting yang harus dilakukan oleh pengelola lembaga zakat adalah meningkatkan sosialisasi sistem lembaga zakat melalui media massa yang efektif, sehingga pengetahuan masyarakat mengenai lembaga zakat tidak hanya 
terbatas pada lembaga yang menyalurkan dana zakat saja.

Oleh karena itu upaya untuk meningkatkan pengetahuan masyarakat tentang lembaga zakat menjadi isu strategis dalam pengembangan lembaga zakat di masa yang akan datang. Semakin baik pengetahuan tentang lembaga zakat semakin tinggi kemungkinan untuk memilih penyaluran dana lewat lembaga zakat. Sebagian besar masyarakat yang mengadopsi lembaga zakat masih dominan dipengaruhi oleh emosi keagamaan belum berdasarkan pada pemahaman rasional yang baik.

$$
\text { Mengetahui pentingnya }
$$

pengetahuan konsumen tentang lembaga zakat, Baitul Maal Hidayatullah diharapkan dapat mengetahui dengan cara apa perusahaan dapat memenuhi kebutuhan dan keinginan muzakki.

$$
\text { Memahami pengetahuan }
$$
konsumen penting bagi pemasar karena apa yang dibeli, berapa banyak yang dibeli, dimana membeli, dan kapan membeli, akan tergantung kepada pengetahuan konsumen mengenai halhal tersebut. Oleh karena itu, pengetahuan konsumen akan mempengaruhi keputusan pembelian. Ketika konsumen memiliki pengetahuan yang lebih banyak, maka ia akan lebih baik dalam mengambil keputusan. Ia akan lebih efisien dan lebih tepat dalam mengolah informasi serta mampu mengingat kembali informasi tentang produk dengan lebih baik.
Menurut Engel, Blackwell, dan Miniard (1995:315) pengetahuan konsumen adalah faktor penentu utama dari perilaku konsumen. Apa yang konsumen beli, di mana mereka membeli, dan kapan mereka membeli akan bergantung pada pengetahuan yang relevan dengan keputusan.

\section{B. Rumusan Masalah}

Berdasarkan uraian di atas, maka permasalahan yang dihadapi adalah sebagai berikut: Apakah pengetahuan produk (produk sebagai seperangkat ciri, produk sebagai perangkat manfaat, produk sebagai pemuas nilai) memiliki pengaruh terhadap keputusan menjadi donatur Baitul Maal Hidayatullah Cabang Kediri?

\section{Tujuan Penelitian}

Tujuan dari penelitian ini adalah untuk mengetahui pengaruh pengetahuan produk (produk sebagai seperangkat ciri, produk sebagai perangkat manfaat, produk sebagai pemuas nilai) terhadap keputusan menjadi donatur Baitul Maal Hidayatullah Cabang Kediri.

\section{LANDASAN TEORI \\ PENGEMBANGAN HIPOTESIS}

\section{A. Organisasi Nirlaba}

Organisasi nirlaba ialah organisasi yang didirikan sebagai ekspresi keinginan sekelompok orang untuk membantu orang lain yang belum mampu memenuhi kebutuhan sosialnya sendiri. Wirjana, 2007:185).

\section{B. Organisasi dalam Pengelolaan Zakat}

Organisasi pengelola zakat (OPZ) adalah sebuah institusi yang bertugas 
dalam pengelolaan zakat, infaq, dan shadaqah, baik yang dibentuk oleh pemerintah seperti $B A Z$, maupun yang dibentuk oleh masyarakat dan dilindungi oleh pemerintah seperti LAZ. Menurut UU No. 23 Tahun 2011 dinyatakan bahwa, "Pengelolaan zakat adalah kegiatan perencanaan, pelaksanaan, dan pengoordinasian dalam pegumpulan, pendistribusian, dan pendayagunaan zakat." Berdasarkan peraturan perundang-undangan, di Indonesia terdapat dua jenis Organisasi Pengelola Zakat, yaitu Badan Amil Zakat (BAZ) dan Lembaga Amil Zakat (LAZ).

\section{Pemasaran Islam}

Definisi pemasaran syariah oleh Kartajaya dan Sula (2006:26) adalah sebuah disiplin bisnis strategis yang dalam keseluruhan prosesnya sesuai dengan akad dan prinsip-prinsip muamalah (bisnis) dalam Islam, untuk mencari ridho Allah SWT (Ratnasari, 2009).

\section{Pemasaran Jasa}

Kotler dan Armstrong (2008:266) mendefinisikan jasa adalah semua kegiatan atau manfaat yang dapat ditawarkan suatu pihak kepada pihak lain, yang pada dasarnya tak berwujud (intangible) dan tidak menghasilkan kepemilikan akan sesuatu.

\section{E. Perilaku Konsumen}

Kotler dan Keller (2009:166)
mendefinisikan perilaku konsumen
sebagai studi tentang bagaimana
individu, kelompok, dan organisasi
memilih, membeli, menggunakan, dan
bagaimana barang, jasa, ide, atau

pengalaman untuk memuaskan kebutuhan dan keinginan mereka.

Muflih (2006:4) mengatakan bahwa perilaku konsumen dalam Islam harus mencerminkan hubungan dirinya dengan Allah SWT sehingga konsumen akan lebih memilih jalan yang dibatasi Allah SWT dengan tidak memilih barang haram, tidak kikir, dan tidak tamak supaya hidupnya selamat baik di dunia maupun di akhirat. (al-Baqarah ayat 168-169)

\section{F. Faktor yang Mempengaruhi Perilaku Pembelian Konsumen}

Engel, Blackwell dan Miniard (1995:46) berpendapat bahwa ada tiga kategori yang mendasari perilaku konsumen: (1) pengaruh lingkungan; (2) perbedaan dan pengaruh individu; (3) proses psikologis.

\section{G. Proses Keputusan Pembelian Konsumen} Menurut Kotler dan Armstrong (2009:184), periset pemasaran telah mengembangkan model tingkat proses keputusan pembelian konsumen melalui lima tahap. Yaitu, Pengenalan Masalah, Pencarian Informasi, Evaluasi Alternatif, Keputusan Pembelian, dan Perilaku Pascapembelian.

Konsumen muslim setelah mengenali masalah akan melakukan pencarian informasi dan evaluasi alternatif. Konsep maslahah menganut persepsi tentang menolak kemudharatan, persepsi kebutuhan Islami, dan persepsi bahwa segala sesuatu dilakukan oleh manusia adalah untuk mencari ridho Allah SWT (persepsi tentang mardhatillah). 
Menurut Muflih (2006:84) kepuasan yang hakiki, hanya ada pada konsumsi di jalan Allah, seperti zakat, infaq, dan shodaqoh. Menurut Metwally (1995, dalam Muflih 2006:84) hal ini terjadi karena bagi seorang konsumen Muslim mengeluarkan shodaqoh merupakan suatu investasi yang akan memberikan daya pikat yang tinggi, tidak saja akan dirasakannya di dunia, tetapi juga di akhirat (al-Baqarah ayat 261) .

\section{H. Pengetahuan Konsumen}

Engel, Blackwell and Miniard (1995:316) secara umum pengetahuan dapat didefinisikan sebagai informasi yang disimpan di dalam ingatan. Himpunan bagian dari informasi total yang relevan dengan fungsi konsumen di dalam pasar disebut pengetahuan konsumen.

Engel, Blackwell, dan Miniard (1995:317) membagi pengetahuan konsumen ke dalam tiga jenis pengetahuan : Pengetahuan Produk, Pengetahuan Pembelian, Pengetahuan Pemakaian.

\section{Pengetahuan Produk}

Menurut Peter dan Olson (1999:69) konsumen dapat memiliki tiga jenis pengetahuan produk: Produk sebagai seperangkat ciri, Produk sebagai perangkat manfaat, dan Produk sebagai pemuas nilai.

\section{J. Hubungan antar Variabel}

Menurut Engel, Blackwell, dan Miniard (1995:316), pengetahuan konsumen terdiri dari informasi yang disimpan di dalam ingatan. Pemasar khususnya tertarik untuk mengetahui pengetahuan konsumen. Informasi yang dipegang oleh konsumen mengenai produk akan sangat mempengaruhi pola konsumsi. Analisis kesadaran dan citra sangat berguna untuk menjajaki sifat pengetahuan produk. Pengetahuan konsumen adalah faktor penentu utama dari perilaku konsumen. Apa yang konsumen beli, di mana mereka membeli, dan kapan mereka membeli akan bergantung pada pengetahuan yang relevan dengan keputusan. Pengaruh yang mendasari perilaku konsumen adalah pengaruh lingkungan, pengaruh individu, dan pengaruh psikologis. Dalam hal ini unsur pengetahuan termasuk ke dalam pengaruh individu.

Engel, Blackwell, dan Miniard (1995:317) membagi pengetahuan konsumen ke dalam tiga jenis pengetahuan, yaitu pengetahuan produk, pengetahuan pembelian, dan pengetahuan pemakaian. Menurut Peter dan Olson (1999:69) konsumen dapat memiliki tiga jenis pengetahuan produk, yaitu produk sebagai seperangkat ciri, produk sebagai perangkat manfaat, produk sebagai pemuas nilai.

Berdasarkan Gambar 2.1, Engel, Blackwell, dan Miniard (1995:60) menyatakan bahwa proses keputusan pembelian dipengaruhi oleh beberapa faktor yang salah satunya adalah perbedaan individu. Setiap individu konsumen memiliki pengetahuan produk yang berbeda-beda dan pengetahuan yang dimiliki oleh konsumen tersebut 
memiliki pengaruh pada keputusan pembelian. Ketika konsumen memiliki pengetahuan yang lebih banyak, maka ia akan lebih baik dalam mengambil keputusan. la akan lebih efisien dan lebih tepat dalam mengolah informasi serta mampu mengingat kembali informasi tentang produk dengan lebih baik.

\section{METODE PENELITIAN}

\section{A. Pendekatan Penelitian}

Jenis penelitian yang digunakan dalam penelitian ini adalah penelitian kuantitatif dengan format deskriptif survei. Menurut Santoso (2010:11) penelitian kuantitatif dengan menggunakan format deskriptif bertujuan untuk menjelaskan, meringkaskan berbagai kondisi, berbagai situasi, atau berbagai variabel yang timbul di masyarakat, yang menjadi obyek penelitian ini, berdasarkan apa yang terjadi. Kemudian mengangkat ke permukaan karakter atau gambaran tentang kondisi, situasi ataupun variabel tersebut. Pada umumnya penelitian ini menggunakan statistik induktif untuk menganalisis data penelitiannya. Data yang terkumpul bisa data kuantitatif maupun kualitatif (Silalahi, 2003:56).

\section{B. Identifikasi Variabel}

Variabel yang digunakan dalam penelitian ini terdiri dari variabel eksogen dan variabel endogen. Variabel-variabel tersebut adalah :

1. Variabel eksogen (X) yaitu pengetahuan produk, yang terdiri dari Pengetahuan Produk, yang terdiri dari Produk sebagai Seperangkat Ciri (Bundle of Attributes), Produk sebagai
Perangkat Manfaat (Bundle of Benefits) , dan Produk sebagai Pemuas Nilai (Value Satisfiers).

2. Variabel endogen (Y) yaitu keputusan menjadi donatur

Variabel-variabel di atas diukur dengan menggunakan skala Likert. Dengan skala Likert, variabel yang akan diukur dijabarkan menjadi indikator variabel. Selanjutnya indikator tersebut dijadikan titik tolak untuk menyusun itemitem instrumen yang dapat berupa pertanyaan atau pernyataan (Sugiyono, dalam Anshori dan Iswati, 2009:67). Rentang skala dalam pengukuran ini dimulai dari angka 1 sampai 4. Masingmasing item diberi 4 pilihan jawaban yang terdiri dari:

Variabel X

1. Kategori sangat mengetahui $=$ skor 4

2. Kategori mengetahui $=$ skor 3

3. Kategori tidak mengetahui $=$ skor 2

4. Kategori sangat tidak mengetahui $=$ skor 1

Variabel $Y$

1. Kategori sangat setuju $=$ skor 4

2. Kategori setuju $=$ skor 3

3. Kategori tidak setuju $=$ skor 2

4. Kategori sangat tidak setuju $=$ skor 1

C. Populasi dan Sampel

Populasi dalam penelitian ini adalah seluruh donatur di Baitul Mall Hidayatullah Cabang Kediri. Donatur yang dimaksud adalah donatur rutin yang menyumbangkan dana ZIS setiap bulannya. Sampel yang digunakan dalam penelitian ini adalah sebanyak 75 donatur Baitul Maal Hidayatullah Cabang Kediri 


\section{Metode Pengambilan Sampel}

Pengambilan sampel dalam populasi tersebut dilakukan dengan teknik pengambilan sampel probabilitas (probability sampling) yang berarti bahwa setiap anggota populasi mempunyai peluang yang sama untuk menjadi sampel (Anshori dan Iswati, 2009:101). Probability sampling yang digunakan adalah simple random sampling karena pengambilan sampel anggota populasi dilakukan secara acak tanpa memperhatikan strata yang ada dalam populasi itu.

Dari data yang telah didapat, diketahui bahwa jumlah donatur di Baitul Mal Hidayatullah Kediri yang memenuhi kualifikasi di atas adalah sebanyak 300 orang.

Penentuan jumlah sampel menurut Slovin (Umar, 2003) adalah sebagai berikut:

$$
n=\frac{N}{1+N e^{2}}
$$

$\mathrm{n}=$ ukuran sampel

$\mathrm{N}=$ ukuran populasi

$E$ = nilai kritis atau batas ketelitian yang digunakan

Berdasar rumus diatas, maka jumlah sampel minimal yang harus diperoleh untuk penelitian berjumlah 75 responden dengan perhitungan sebagai berikut:

1. $\mathrm{N}=$ Jumlah donatur $\mathrm{BMH}$ di Kediri 300 orang

2. $e=10 \%$

$$
n=\frac{300}{1+300(0,1)^{2}}
$$

$$
\begin{gathered}
n=\frac{300}{1+3} \\
n=75
\end{gathered}
$$

Dalam penelitian ini telah dilaksanakan penyebaran kuesioner kepada 75 orang donatur Baitul Maal Hidayatullah Cabang Kediri. Penyebaran kuesioner dilakukan dengan bantuan pihak fundrising yang saat itu bertugas menghimpun dana door to door ke rumah masing-masing donatur.

\section{E. Uji Validitas dan Reliabilitas}

Suatu skala pengukuran disebut valid apabila melakukan apa yang seharusnya dilakukan dan mengukur apa yang seharusnya diukur (Kuncoro, 2003:151). Skala pengukuran menjadi tidak berguna atau bermanfaat apabila skala pengukuran tidak valid, karena tidak mengukur apa yang seharusnya diukur atau tidak melakukan apa yang seharusnya dilakukan. Tiap item indikator dinyatakan valid jika nilai koefisien korelasinya diatas 0,30, namun Azwar (1997:45) menyatakan bahwa batas kriteria kevalidan suatu item dapat diturunkan menjadi 0,25, namun tidak disarankan jika kriteria kevalidan berada di bawah 0,20.

Reliabilitas menurut Nazir (2003:133) adalah menyangkut ketepatan alat ukur. Suatu alat ukur mempunyai reliabilitas tinggi atau dapat dipercaya apabila alat ukur itu mantap atau stabil, dapat diandalkan dan dapat diramalkan. Keseluruhan indikator dianggap sudah cukup reliabel bilamana $a \geq 0,6$. 


\section{F. Teknik Analisis}

Dalam menganalisis data penelitian ini digunakan uji statistik dengan analisa regresi linier berganda untuk menguji pengaruh antara Produk sebagai Seperangkat Ciri (Bundle of Attributes) $\left(X_{1}\right)$, Produk sebagai Perangkat Manfaat (Bundle of Benefits) $\left(X_{2}\right)$, dan Produk sebagai Pemuas Nilai (Value Satisfiers) ( $\left.X_{3}\right)$ terhadap keputusan menjadi donatur $(\mathrm{Y})$.

Persamaan regresi linier berganda:

$Y=a+\beta_{1} X_{1}+\beta_{2} X_{2}+\beta_{3} X_{3}+e$

Dimana :

$Y=$ Keputusan menjadi donatur Baitul Maal Hidayatullah Cabang Kediri

$a=$ Konstanta

e = suku kesalahan, berdistribusi normal dengan rata-rata 0 , untuk tujuan perhitungan e diasumsikan 0

$\beta 1, \beta 2, \beta 3=$ koefisien regresi yang ditaksir dengan $\mathrm{n}$ buah pasangan data yang didapat dari persamaan

$X_{1}=$ Produk sebagai Seperangkat Ciri (Bundle of Attributes)

$\mathrm{X}_{2}=$ Produk sebagai Perangkat Manfaat (Bundle of Benefits)

$\mathrm{X}_{3}=$ Produk sebagai Pemuas Nilai (Value Satisfiers)

\section{DESKRIPSI HASIL DAN PEMBAHASAN}

Teknik analisis data dalam penelitian ini menggunakan teknik regresi linier berganda. Pemilihan teknik tersebut berdasarkan tujuan untuk mengetahui pengaruh variabel eksogen yang berjumlah lebih dari satu terhadap variabel endogen dengan data yang berskala interval. Dari perhitungan regresi linear berganda maka dihasilkan perolehan sebagaimana ditunjukkan pada tabel 1.1.

Tabel 1.

Hasil Uji Regresi Linier Berganda

\begin{tabular}{|c|c|c|c|c|}
\hline \multirow{2}{*}{ Variabel } & \multicolumn{2}{|c|}{ Koefisien } & \multirow[b]{2}{*}{ t hit. } & \multirow[b]{2}{*}{ Sign. } \\
\hline & $\begin{array}{l}\text { Koef. } \\
\text { Reg. }\end{array}$ & Beta & & \\
\hline Konstanta & 0,409 & 0 & $\begin{array}{l}1,3 \\
71\end{array}$ & 0,175 \\
\hline $\begin{array}{l}\text { Pengetah } \\
\text { van } \\
\text { Produk } \\
\text { sebagai } \\
\text { Seperang } \\
\text { kat Ciri } \\
\left(X_{1}\right)\end{array}$ & 0,473 & $\begin{array}{r}0,5 \\
49\end{array}$ & $\begin{array}{r}6,9 \\
35\end{array}$ & 0,000 \\
\hline $\begin{array}{l}\text { Pengetah } \\
\text { van } \\
\text { Produk } \\
\text { sebagai } \\
\text { Perangkat } \\
\text { Manfaat } \\
\left(X_{2}\right)\end{array}$ & 0,194 & $\begin{array}{r}0,2 \\
62\end{array}$ & $\begin{array}{r}3,3 \\
56\end{array}$ & 0,001 \\
\hline $\begin{array}{l}\text { Pengetah } \\
\text { van } \\
\text { Produk } \\
\text { sebagai } \\
\text { Pemuas } \\
\text { Nilai }\left(X_{3}\right) \\
\end{array}$ & 0,214 & $\begin{array}{l}0,2 \\
79\end{array}$ & $\begin{array}{r}3,6 \\
17\end{array}$ & 0,001 \\
\hline \multicolumn{2}{|c|}{$\begin{array}{l}\text { Multiple } R=0,771 \\
N=75 \\
\text { R Square }=0,594\end{array}$} & $\begin{array}{l}\text { F Hitc } \\
\text { Sign }\end{array}$ & \multicolumn{2}{|c|}{$=34.687$} \\
\hline Sumber: & tasil & $\frac{\text { slgni }}{\text { elitia }}$ & & U \\
\hline
\end{tabular}

Kemampuan variabel bebas dalam menerangkan atau menjelaskan perubahan variabel terikat dapat dilihat dari nilai koefisien determinasi berganda $\left(R^{2}\right)$. semakin tinggi nilai $R^{2}$ maka semakin baiklah model tersebut. Nilai dari $R^{2}$ berkisar antara 0 sampai 1, semakin mendekati 1 maka semakin baik kemampuan variabel bebas dalam menjelaskan variabel terikat dalam model. Nilai dari koefisien determinasi dari 
hasil perhitungan adalah 0,594 yang berarti bahwa sebesar 59,4\% Keputusan Menjadi Donatur (variabel endogen) mampu dijelaskan oleh variabel eksogen yang dimasukkan dalam model Pengetahuan Produk sebagai Seperangkat Ciri, Pengetahuan Produk sebagai Perangkat Manfaat, dan Pengetahuan Produk sebagai Pemuas Nilai secara simultan, sedangkan 40,6\% dijelaskan oleh variabel lain yang tidak dimasukkan dalam model.

Berdasarkan hasil analisis regresi berganda diperoleh nilai koefisien korelasi berganda atau Multiple (R) sebesar 0,771. Koefisien ini menunjukkan tingkat hubungan atau korelasi variabel endogen Keputusan Menjadi Donatur (Y) terhadap variabel-variabel eksogen Pengetahuan Produk sebagai Seperangkat Ciri, Pengetahuan Produk sebagai Perangkat Manfaat, dan Pengetahuan Produk sebagai Pemuas Nilai. Nilai $R$ yang cukup tinggi, yaitu sebesar 0,771 menunjukkan adanya hubungan yang kuat antara semua varibel eksogen Pengetahuan Produk sebagai Seperangkat Ciri, Pengetahuan Produk sebagai Perangkat Manfaat, dan Pengetahuan Produk sebagai Pemuas Nilai dengan variabel endogen Keputusan Menjadi Donatur (Y).

Maka, berdasarkan Tabel 1.1 di atas dapat dibuat persamaan regresi yang dapat dibuat adalah sebagai berikut :

$$
Y=0,409+0,473 X_{1}+0,194 X_{2}+0,214 X_{3}
$$

Keterangan: $Y=$ Keputusan Menjadi Donatur

$$
\mathrm{X}_{1}=\text { Pengetahuan Produk }
$$

sebagai Seperangkat Ciri

$\mathrm{X}_{2}=$ Pengetahuan Produk sebagai Perangkat Manfaat

$$
X_{3}=\text { Pengetahuan Produk }
$$

sebagai Pemuas Nilai

Berdasarkan data hasil regresi pada tabel 1.1 diketahui bahwa nilai $\mathrm{F}$ hasil regresi adalah sebesar 34,687 , dengan nilai probabilitas kesalahan (Sig) sebesar 0,000. Nilai signifikansi ini lebih kecil dari 0,05 sehingga Pengetahuan Produk sebagai Seperangkat Ciri, Pengetahuan Produk sebagai Perangkat Manfaat, dan Pengetahuan Produk sebagai Pemuas Nilai secara simultan berpengaruh terhadap keputusan menjadi donatur Baitul Maal Hidayatullah Cabang Kediri.

Sedangkan untuk mengetahui pengaruh variabel secara parsial, dilakukan uji † untuk mengetahui pengaruh masing-masing variabel eksogen secara individual terhadap variabel endogen dalam satu model. Berikut hasil uji parsial selengkapnya:

Tabel 2.

\section{Hasil Uji Regresi secara parsial (Uji t)}

\begin{tabular}{|l|c|c|}
\hline \multicolumn{1}{|c|}{ Variabel } & $\mathbf{t}$ & $\begin{array}{c}\text { Tingkat } \\
\text { signifikansi }\end{array}$ \\
\hline $\begin{array}{l}\text { Pengetahuan } \\
\text { Produk } \\
\text { sebagai } \\
\text { Seperangkat } \\
\text { Ciri }\end{array}$ & 6,935 & 0,000 \\
\hline $\begin{array}{l}\text { Pengetahuan } \\
\text { Produk } \\
\text { sebagai }\end{array}$ & 3,356 & 0,001 \\
$\begin{array}{l}\text { Perangkat } \\
\text { Manfaat }\end{array}$ & 3,617 & 0,001 \\
\hline $\begin{array}{l}\text { Pengetahuan } \\
\text { Produk } \\
\text { sebagai } \\
\text { Pemuas Nilai }\end{array}$ & & \\
\hline
\end{tabular}


Sumber: Hasil penelitian, 2014 (data diolah)

Berdasarkan tabel 1.2 dapat dijelaskan sebagai berikut:

1. Pengetahuan Produk sebagai Seperangkat Ciri

Formulasi hipotesis statistik $\mathrm{Ho}=\beta_{1}=0 ; \mathrm{Ha}$ $\neq \beta_{1} \neq 0$

Nilai uji $†$ untuk variabel Pengetahuan Produk sebagai Seperangkat Ciri $\left(X_{1}\right)$ adalah sebesar 6,935 dengan tingkat signifikasi 0,000 . Nilai signifikasi ini lebih lebih kecil dari 0,05, sehingga dapat dinyatakan Pengetahuan Produk sebagai Seperangkat Ciri secara parsial berpengaruh terhadap keputusan menjadi donatur Baitul Maal Hidayatullah Cabang Kediri.

2. Pengetahuan Produk sebagai Perangkat Manfaat

Formulasi hipotesis statistik $\mathrm{Ho}=\beta_{2}=0 ; \mathrm{Ha}$ $\neq \beta_{2} \neq 0$

Nilai uji $\dagger$ untuk variabel Pengetahuan Produk sebagai Perangkat Manfaat $\left(X_{2}\right)$ adalah sebesar 3,356 dengan tingkat signifikasi 0,001 . Nilai signifikasi ini lebih lebih kecil dari 0,05, sehingga dapat dinyatakan Pengetahuan Produk sebagai Perangkat Manfaat secara parsial berpengaruh terhadap keputusan menjadi donatur Baitul Maal Hidayatullah Cabang Kediri.

3. Pengetahuan Produk sebagai Pemuas Nilai

Formulasi hipotesis statistik $\mathrm{Ho}=\beta_{3}=0 ; \mathrm{Ha}$ $\neq \beta_{3} \neq 0$

Nilai uji $\dagger$ untuk variabel Pengetahuan Produk sebagai Pemuas Nilai $\left(X_{3}\right)$ adalah sebesar 3,617 dengan tingkat signifikasi 0,001 . Nilai signifikasi ini lebih kecil dari 0,05, sehingga dapat dinyatakan Pengetahuan Produk sebagai Pemuas Nilai secara parsial berpengaruh terhadap keputusan menjadi donatur Baitul Maal Hidayatullah Cabang Kediri.

Dari pengujian hipotesis di atas, bisa disimpulkan bahwa seluruh variabel eksogen, yaitu Pengetahuan Produk sebagai Seperangkat Ciri, Pengetahuan Produk sebagai Perangkat Manfaat, dan Pengetahuan Produk sebagai Pemuas Nilai memiliki pengaruh secara parsial yang signifikan terhadap keputusan menjadi donatur Baitul Maal Hidayatullah Cabang Kediri.

\section{A. Uji Multikolinieritas}

Gejala multikolinearitas adalah gejala baru atau kolinearitas ganda antar variabel bebas. Deteksi adanya gejala multikolinearitas pada model regresi diuji dengan menggunakan Variance Inflation Factor (VIF). Multikolinearitas terjadi apabila nilai $\mathrm{VIF} \geq 10$. hasil pengujian multikolinearitas dalam penelitian ini ditunjukkan dalam tabel berikut ini :

Tabel 3

Statistik Kolinearitas

\begin{tabular}{|c|c|c|}
\hline Variabel & $\begin{array}{c}\text { Nilai } \\
\text { VIF }\end{array}$ & Keterangan \\
\hline $\begin{array}{c}\text { Pengetahuan } \\
\text { Produk sebagai } \\
\text { Seperangkat } \\
\text { Ciri }\left(X_{1}\right)\end{array}$ & 1,099 & Tidak terjadi \\
multikolinieritas \\
\hline $\begin{array}{c}\text { Pengetahuan } \\
\text { Produk sebagai }\end{array}$ & 1,069 & $\begin{array}{c}\text { Tidak terjadi } \\
\text { multikolinieritas }\end{array}$ \\
\hline
\end{tabular}




\begin{tabular}{|c|c|c|}
\hline $\begin{array}{c}\text { Perangkat } \\
\text { Manfaat }\left(X_{2}\right)\end{array}$ & & \\
\hline $\begin{array}{c}\text { Pengetahuan } \\
\text { Produk sebagai } \\
\text { Pemuas Nilai } \\
\left(X_{3}\right)\end{array}$ & 1,043 & Tidak terjadi \\
multikolinieritas \\
\hline
\end{tabular}

Sumber: Hasil Output SPSS (Lampiran)

Tabel di atas menunjukkan bahwa semua variabel bebas mempunyai nilai $\mathrm{VIF}<10$.

Hal ini dapat disimpulkan bahwa pada model regresi tidak terjadi

multikolinearitas.

\section{B. Uji Heteroskedastisitas}

Pengujian

gejala

heteroskedastisitas dilakukan untuk mengetahui ada tidaknya hubungan antara variabel pengganggu dengan variabel bebasnya. Gejala heterokedastisitas ini diketahui dengan melihat ada tidaknya pola tertentu pada grafik scatterplot, dimana sumbu $X$ adalah $Y$ yang telah diprediksi dan sumbu $X$ adalah residual $(Y$ prediksi $-Y$ sesungguhnya yang telah di-studentized). Dasar pengambilan keputusan :

1. Jika ada pola tertentu, seperti titik-titik (poin-poin) yang ada membentuk suatu pola tertentu yang teratur (bergelombang, melebar kemudian menyempit), maka telah terjadi heteroskedastisitas.

2. Jika tidak ada pola yang jelas, serta titik-titik menyebar di atas dan di bawah angka 0 pada sumbu $Y$, maka tidak terjadi heteroskedastisitas.

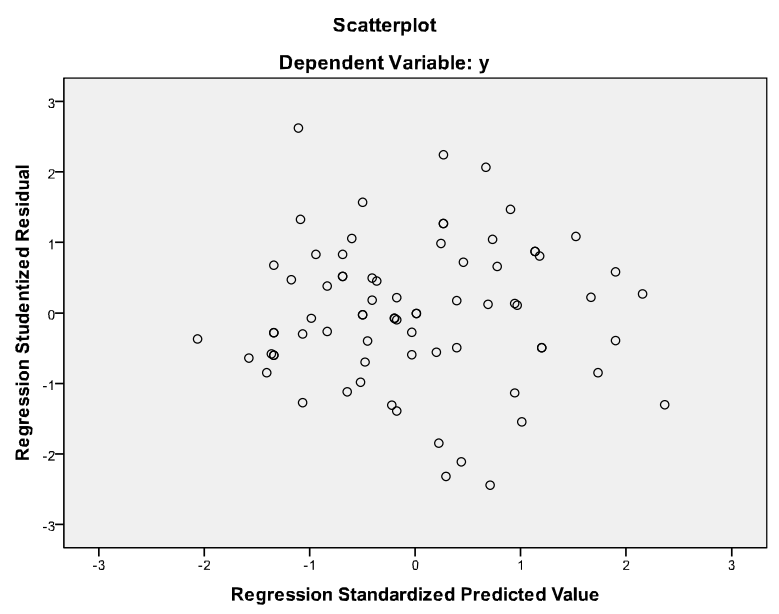

Sumber: Hasil Output SPSS (Lampiran)

\section{Gambar 1.}

\section{Grafik Scatterplot}

Dari Gambar 1. menyajikan titik-titik yang menyebar dan tidak membentuk pola tertentu, maka dapat dinyatakan bahwa tidak terjadi gejala heteroskedastisitas.

\section{Uji Normalitas Data}

Uji normalitas data menunjukkan bahwa variabel pengganggu atau residual model regresi terdistribusi secara normal.

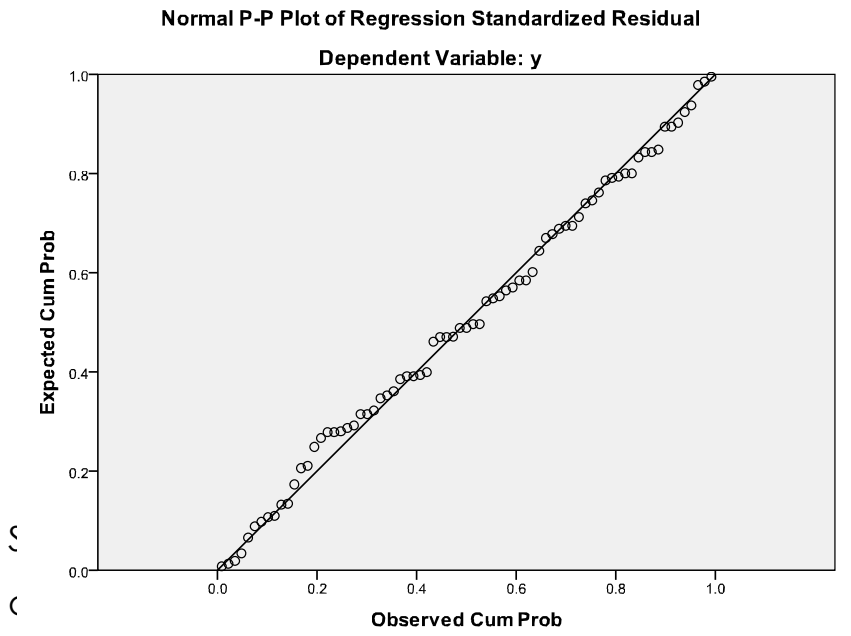

Gambar 2.

Grafik Normalitas Data 
Dari Gambar 2 menyajikan bahwa titik-titik menyebar secara teratur di sekitar sumbu $Y$, sehingga dapat dinyatakan bahwa data yang digunakan adalah normal, atau dapat digunakan untuk memprediksi keputusan menjadi donatur Baitul Maal Hidayatullah Cabang Kediri melalui pengetahuan produk.

\section{Analisis dan Pembahasan}

Analisis regresi dalam penelitian ini menghasilkan model sebagai berikut:

$$
Y=0,409+0,473 X_{1}+0,194 X_{2}+0,214 X_{3}
$$

Keterangan: $Y=$ Keputusan Menjadi Donatur

$$
X_{1}=\text { Pengetahuan Produk }
$$

sebagai Seperangkat Ciri

$$
\mathrm{X}_{2}=\text { Pengetahuan Produk }
$$

sebagai Perangkat Manfaat

$$
X_{3}=\text { Pengetahuan Produk }
$$

sebagai Pemuas Nilai

Pembahasan model yang diperoleh dalam analisis regresi adalah sebagai berikut:

\section{E. Proporsi Pengaruh Variabel Penelitian}

Hasil pengujian menunjukkan bahwa Pengetahuan Produk sebagai Seperangkat Ciri $\left(X_{1}\right)$, Pengetahuan Produk sebagai Perangkat Manfaat $\left(X_{2}\right)$, dan Pengetahuan Produk sebagai Pemuas Nilai $\left(X_{3}\right)$ memiliki proporsi pengaruh sebesar $59,4 \%$ terhadap Keputusan Menjadi Donatur Baitul Maal Hidayatullah Cabang Kediri, sedangkan 40,6\% dijelaskan oleh variabel lain yang tidak dimasukkan dalam model.

\section{F. Pembahasan Uji Hipotesis Bersama- sama}

Hasil uji-F menjelaskan bahwa variabel pengetahuan produk sebagai seperangkat ciri, pengetahuan produk sebagai perangkat manfaat, dan pengetahuan produk sebagai pemuas nilai memiliki pengaruh yang simultan terhadap keputusan menjadi donatur Baitul Maal Hidayatullah cabang Kediri. Hal ini menunjukkan bahwa Baitul Maal Hidayatullah Kediri telah membuka diri, mensosialisasikan, dan menjalankan peran dan tugasnya sebagai Lembaga Amil Zakat dengan baik dan sesuai dengan visi dan misinya.

\section{G. Pengaruh Variabel Pengetahuan}

Produk sebagai Seperangkat Ciri, Pengetahuan Produk sebagai Perangkat Manfaat, dan Pengetahuan Produk sebagai Pemuas Nilai terhadap Keputusan Menjadi Donatur Baitul Maal Hidayatullah Cabang Kediri

Uji - $\dagger$ menyatakan pengaruh variabel eksogen (X) secara parsial terhadap variabel endogen (Y). Hasil pengujian menunjukkan bahwa variabel pengetahuan produk sebagai seperangkat ciri $\left(X_{1}\right)$, pengetahuan produk sebagai perangkat manfaat $\left(X_{2}\right)$, dan pengetahuan produk sebagai pemuas nilai $\left(X_{3}\right)$ secara parsial berpengaruh signifikan terhadap keputusan menjadi donatur Baitul Maal Hidayatullah cabang Kediri. 
H. Pengaruh Pengetahuan Produk sebagai Seperangkat Ciri terhadap Keputusan

Menjadi Donatur Baitul Maal
Hidayatullah Cabang Kediri

Dari hasil analisis regresi diketahui bahwa pengetahuan produk sebagai seperangkat ciri $\left(X_{1}\right)$ memiliki hubungan positif yang signifikan terhadap keputusan menjadi donatur Baitul Maal Hidayatullah cabang Kediri. Koefisien beta yang diperoleh dari hasil analisis regresi menunjukkan bahwa pengetahuan produk sebagai perangkat ciri lebih dominan pengaruhnya dibandingnya variabel lainnya, yaitu sebesar 0,549. Menurut Peter dan Olson (1999:69), pengetahuan mengenai ciri produk jasa akan mempengaruhi pengambilan keputusan konsumen. Pengetahuan yang lebih banyak mengenai ciri suatu produk jasa akan memudahkan konsumen untuk memilih produk jasa yang akan digunakannya. Strategi pemasaran terutama dalam komunikasi sering diarahkan untuk menyampaikan informasi mengenai atribut-atribut baru yang dimiliki oleh suatu produk jasa tersebut, dengan harapan bahwa atribut tersebut memberikan nilai tambah di mata konsumen.

Konsumen memiliki berbagai tingkatan pengetahuan tentang ciri produk. Pengetahuan tentang ciri abstrak (abstract attributes) mewakili karakteristik subjektif tak nyata dari suatu produk jasa. Salah satu contoh yakni kualitas pelayanan dan kenyamanan dari sebuah layanan jasa. Pengetahuan tentang ciri konkrit (concrete attributes) mewakili karakteristik nyata suatu produk seperti keragaman produk jasa yang ditawarkan. Disamping itu, pengetahuan ciri konsumen juga berisikan evaluasi afeksi dari setiap ciri (saya tidak suka pelayanan jasa yang tidak ramah; saya suka pelayanan jasa yang profesional).

\section{Pengaruh Pengetahuan Produk sebagai} Perangkat Manfaat terhadap Keputusan Menjadi Donatur Baitul Maal Hidayatullah Cabang Kediri

Dari hasil analisis regresi diketahui bahwa pengaruh pengetahuan produk sebagai perangkat manfaat $\left(X_{2}\right)$ memiliki hubungan positif yang signifikan terhadap keputusan menjadi donatur Baitul Maal Hidayatullah cabang Kediri dengan nilai beta $X_{1}$ sebesar 0,262. Seperti yang dinyatakan Peter dan Olson (1999:69), konsumen sering berpikir tentang produk dan merek dalam konteks konsekuensinya. Konsekuensi adalah apa yang terjadi pada konsumen ketika suatu produk dibeli dan digunakan atau dikonsumsi. Konsumen dapat memiliki pengetahuan tentang dua jenis konsekuensi produk, yaitu fungsional dan psikososial. Konsekuensi fungsional adalah dampak tak nyata dari penggunaan suatu produk jasa yang dialami konsumen. Contoh-contoh konsekuensi fungsional adalah dampak fisiologis langsung yang dirasakan pada saat menggunakan produk jasa tersebut (menggunakan jasa laboratorium klinik medis memberikan kepastian dan menghilangkan keraguan terkait kondisi kesehatan). Konsekuensi 
psikososial mengacu pada dampak psikologis dan sosial dari penggunaan suatu produk. Konsekuensi psikologis penggunaan produk adalah dampak internal pribadi seperti bagaimana suatu produk membuat konsumen "merasakan". Misalnya menginap di Hotel Hilton dapat membuat anda lebih gaya. Konsumen juga dapat memiliki pengetahuan tentang konsekuensi sosial penggunaan produk (orang akan suka/menghargai saya jika saya menginap di Hotel Hilton).

\section{J. Pengaruh Pengetahuan Produk} sebagai Pemuas Nilai terhadap Keputusan Menjadi Donatur Baitul Maal

\section{Hidayatullah Cabang Kediri}

Dari hasil analisis regresi, diketahui bahwa pengetahuan produk sebagai pemuas nilai $\left(X_{3}\right)$ memiliki hubungan positif yang signifikan terhadap keputusan menjadi donatur Baitul Maal Hidayatullah cabang Kediri dengan nilai koefisien beta sebesar 0,279. Menurut Muflih (2006:84) kepuasan yang hakiki, hanya ada pada konsumsi di jalan Allah, seperti zakat, infaq, dan shodaqoh. Sedangkan menurut Metwally (1995, dalam Muflih 2006:84) hal ini terjadi karena bagi seorang konsumen Muslim mengeluarkan shodaqoh merupakan suatu investasi yang akan memberikan daya pikat yang tinggi, tidak saja akan dirasakannya di dunia, tetapi juga di akhirat. Hal ini dimotivasi lagi oleh Allah:

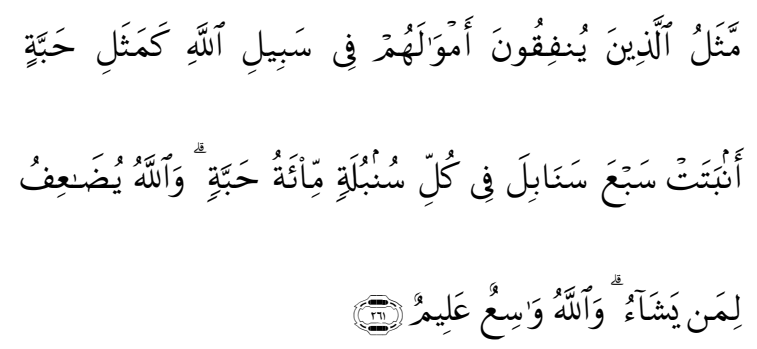

Matsalul-ladziina

yunfiquuna

amwaalahum fii sabiilillahi kamatsali habbatin anbatat sab'a sanaabila fii kulli sunbulatin mii-atu habbatin wallahu yudhaa'ifu liman yasyaa-u wallahu waasi'un 'aliimun

"Artinya: "Perumpamaan (nafkah yang dikelvarkan oleh) orang-orang yang menafkahkan hartanya di jalan Allah adalah serupa dengan sebutir benih yang menumbuhkan tujuh bulir, pada tiap-tiap bulir seratus biji. Allah melipat gandakan (ganjaran) bagi siapa yang Dia kehendaki. dan Allah Maha Luas (karuniaNya) lagi Maha mengetahui".(Qs al Baqarah:261)

Investasi ini akan melimpahkan keberuntungan dan berkah. Hal ini dapat berupa keutungan tak terduga, penemuan yang tidak diperhitungkan sebelumnya, sesuatu yang tidak direncanakan atau bentuk hikmah lainnya

\section{KESIMPULAN DAN SARAN}

\section{A. Simpulan}

Simpulan penelitian pengaruh pengetahuan produk terhadap keputusan menjadi donatur Baitul Maal Hidayatullah Cabang Kediri adalah sebagai berikut:

1. Pengetahuan Produk yang terdiri dari pengetahuan produk sebagai seperangkat ciri, pengetahuan produk 
sebagai perangkat manfaat, dan pengetahuan produk sebagai pemuas nilai secara simultan berpengaruh terhadap keputusan menjadi donatur Baitul Maal Hidayatullah Cabang Kediri.

2. Pengetahuan Produk sebagai Seperangkat Ciri $\left(X_{1}\right)$ berdasarkan hasil analisis regresi linier berganda merupakan variabel eksogen yang dominan mempengaruhi keputusan menjadi donatur Baitul Maal Hidayatullah Cabang Kediri (Y).

\section{B. Saran}

Saran yang direkomendasikan setelah penelitian pengaruh pengetahuan produk terhadap keputusan menjadi donatur Baitul Maal Hidayatullah Cabang Kediri adalah sebagai berikut:

Dengan pengetahuan produk sebagai seperangkat ciri sebagai variabel yang dominan mempengaruhi keputusan menjadi donatur maka hasil penelitian ini dapat digunakan sebagai masukan bagi Baitul Maal Hidayatullah Kediri agar isi bulletin yang disebarkan kepada para calon donatur dan donatur berisi informasi yang lengkap, misalnya yang belum tercantum adalah laporan keuangan. Laporan kevangan hanya ada di media informasi berupa website, mengingat usia responden lebih dari $50 \%$ berusia $>36$ tahun, tidak setiap donatur dapat membuka internet atau yang disebut gaptek. Media Informasi yang berupa buletin disini memegang peranan yang penting, maka diharapkan Baitul Maal
Hidayatullah mengisinya dengan hal yang informatif dan edukatif.

1. Untuk pemerintah hendaknya mendukung program sentralisasi zakat, agar dapat digunakan untuk kepentingan sosial dan pengentas kemiskinan di Indonesia, daripada terus menerus berhutang ke luar negeri.

2. Untuk penelitian selanjutnya akan lebih baik jika meneliti pengetahuan produk dengan indikator yang lebih spesifik dan rinci. Penelitan selanjutnya juga diharapkan dapat meneliti pada lembaga amil zakat yang lain sehingga menambah informasi yang dapat digali mengenai pengetahuan konsumen apakah hasil yang didapat dalam penelitan ini sama dengan penelitian selanjutnya.

\section{DAFTAR PUSTAKA}

Anshori, Muslich dan Sri Iswati. 2009. Buku Ajar Metodologi Penelitian Kuantitatif. Cetakan Pertama. Surabaya: Airlangga University Press.

Engel, F. James; Roger D. Blackwell; Paul W. Miniard. 1995. Perilaku Konsumen. Jakarta : Binarupa Aksara.

Kartajaya, Hermawan dan Muhammad Syakir Sula. 2006. Syariah Marketing. Bandung: PT. Mizan Pustaka.

Kotler, Philip dan Gary Amstrong. 2008. Prinsip-Prinsip Pemasaran. Edisi 12, 
Jilid 1. Terjemahan. Jakarta: Erlangga

dan Kevin Lane Keller. 2009. Manajemen Pemasaran. Edisi 13, Jilid 1. Jakarta: Erlangga.

Kuncoro, Mudrajad. 2011. Metode Kuantitatif: Edisi Keempat. Yogyakarta: UPP STIM YKPN

Muflih, Muhammad. 2006. Perilaku Konsumen Dalam Perspektif IImu Ekonomi Islam. Jakarta: Rajawali Pers.

Peter, J. Paul dan Jerry C. Olson. 1999. Perilaku Konsumen dan Strategi Pemasaran. Edisi Keempat, Jilid 1. Jakarta: Erlangga.

Santoso, Slamet. 2010. Metode Penelitian Kuantitatif: Plus Aplikasi Program SPSS. Ponorogo: P2-FE Universitas Muhammadiyah Ponorogo.
Silalahi, Gabriel Amin.2003. Metodologi Penelitian dan Studi Kasus. Sidoarjo: Citra Media.

Sugiyono. 2010a. Metode Penelitian Kuantitatif Kualitatif dan R\&D. Bandung: Alfabeta. 2010b. Statistika untuk Penelitian. Bandung: Alfabeta.

Sula, Syakir. 2011. Marketing Syariah (Online),

(http://www.syakirsula.com/view/ article/ marketing-syariah/, Diakses Tanggal 17Juli 2013).

Ratnasari, Ririn Tri dan Mastuti H. Aksa. 2009. Slide Perkuliahan Pemasaran Syariah. Surabaya: Fakultas Ekonomi dan Bisnis Universitas Airlangga.

Wirjana, Bernardine E. 2007. Mencapai Manajemen Berkualitas: Organisasi, Kinerja Program. Yogyakarta: Andi Offset 